\title{
KERENTANAN BANGUNAN RUMAH CAGAR BUDAYA TERHADAP GEMPA DI YOGYAKARTA
}

\author{
Muhammad Heri Zulfiar ${ }^{1}$, Arman Jayady ${ }^{2}$, Nurwidi Rukmono Jati Saputra ${ }^{3}$ \\ ${ }^{1}$ Staf Pengajar Jurusan Teknik Sipil, Program Studi Teknik Sipil, Universitas Muhammadiyah Yogyakarta, \\ zulfiarhey@yahoo.com \\ ${ }^{2}$ Staf Pengajar Jurusan Teknik Sipil, Program Studi Diploma IV Teknik Sipil, Politeknik Katolik Saint PauL \\ Sorong, Email: ajayady@yahoo.co.id \\ ${ }^{3}$ Mahasiswa Jurusan Teknik Sipil, Program Studi Teknik Sipil, Universitas Muhammadiyah Yogyakarta
}

\begin{abstract}
Abstrak
Yogyakarta merupakan salah satu provinsi di Indonesia yang memiliki tingkat risiko bencana gempa yang tinggi. Jenis bangunan yang memiliki tingkat resiko tinggi yaitu rumah hunian cagar budaya yang memiliki nilai sejarah yang banyak terdapat di Yogyakarta, salah satunya bangunan yang terletak di daerah nDalem Pujokusuman, jalan Brigjen Katamso Yogyakarta. Bangunan cagarbudaya umumnya telah melebihi usia pakai dan diindikasi tanpa perawatan dan perbaikan memadai seingga berpotensi rentan terhadap gempa .

Tujuan dari penelitian ini adalah melakukan penilaian tingkat kerentanan bangunan rumah hunian cagar budaya terhadap gempa dan mengidentifikasi faktor penyebab kerentanannya gempa dengan menggunakan metode rapid visual screening berdasarkan FEMA P-154 tahun 2015.

Hasil kajian menunjukan bahwa rumah hunian nDalem Pujokusuman Yogyakarta berada pada daerah rawan gempa dengan tingkat ancaman tinggi dan telah dilakukan renovasi tanpa peran ahli memadai (non-engineered). Rumah tersebut rentan terhadap gempa dan berpotensi roboh sebesar 63\% dari seluruh bangunan jika terjadi gempa bumi. Faktor yang menyebabkan bangunan rentan terhadap gempa adalah pada tipe bangunan dengan system konstruksi tidak sesuai, bentuk denah tidak sesuai, adanya spit level ketidak teraturan vertical, detailing belum mengacu pada pembangunan atau code yang berlaku, perawatan dan perbaikan bangunan tidak standar.
\end{abstract}

Kata kunci : FEMA P-154, Gempa, Kerentanan Bangunan, Rapid Visual Screening (RVS)

\section{Pendahuluan}

Indonesia dikenal sebagai negara yang memiliki tingkat bencana alam yang cukup tinggi mulai dari erupsi gunung berapi, tanah longsor, banjir, kebakaran hutan, gempa bumi, dan bencana alam lainya. Bencana alam yang kerap terjadi di Indonesia disebabkan karena Indonesia merupakan negara kepulauan yang terletak pada pertemuan tiga lempeng tektonik, yaitu lempeng hindia - australia, lempeng pasifik, dan lempeng euranasia yang menyebabkan bencana gempa bumi.

Pada tanggal 26 Mei 2006, Yogyakarta di goncang gempa dahsyat yang terjadi pada koordinat 8.03 LS dan 110,32 BT, dengan kedalaman $11,3 \mathrm{~km}$, dan kekuatan $5.9 \mathrm{SR} \mathrm{mb}$ (magnitude body) atau setara $6.3 \mathrm{SR} \mathrm{mm}$ (magnitude moment). Akibat gempa yang terjadi mengakibatkan kerusakan bangunan dari mulai tingkat kerusakan ringan, sedang hingga berat. Dari peristiwa yang terjadi maka bangunan gedung yang berada di daerah rawan gempa, perlu dilakukan mitigasi struktural, mitigasi nonstruktural.

Salah satu jenis bangunan yang memiliki tingkat resiko tinggi yaitu bangunan cagar budaya (bangunan non-engineered) dan rumah hunian lainnya yang terletak di daerah perkampungan Ndalem Pujokusuman, Yogyakarta.

Dalam melakukan penilaian besarnya risiko kerusakan akibat gempa, menggunakan metode kualitatif yang dikembangkan oleh Federal Emergency Management Agency (FEMA). Metode kualitatif bertumpu pada kemampuan penilaian surveyor (subyektifitas) terhadap obyek permasalahan (Sekaran, 2003; Jayady, 2017). Penilaian terhadap obyek penelitian dengan berbasis form yang telah dikembangkan oleh FEMA. Penelitian tersebut dengan melakukan pengamatan bangunan, interview dan pengambilan data sekunder. 
Metode Rapid Visual Screening (RVS) adalah sebuah metode pengamatan secara cepat yang dikembangkan oleh FEMA untuk mengidentifikasi, menginventarisir suatu bangunan secara tampak yang berpotensi berbahaya secara seismik (FEMA-P154, 2015).

Tujuan kajian ini adalah melakukan penilaian untuk :

1. Mengetahui kerentanan bangunan dan faktor penyebabnya pada rumah hunian cagar budaya dan di Ndalem Pujokusuman terhadap gempa berdasarkan pengamatan fisik bangunan.

2. Untuk memperkirakan besarnya tingkat kerusakan bangunan rumah hunian cagar budaya di Ndalem Pujokusuman berdasarkan metode Rapid Visual Screening (RVS) apabila gempa besar terjadi .

\section{Kajian Literatur}

Gempa bumi didefinisikan sebagai getaran yang bersifat alamiah, yang terjadi pada lokasi tertentu, dan sifatnya tidak berkelanjutan.

Besarnya percepatan tanah akibat gempa memberikan pengaruh goncangan yang dirasakan di permukaan, dan ukuran getaran tersebut menggunakan skala MMI atau Modified Mercalli Intensity scale (Kramer. S.L., 2014).

Akibat goncangan permukaan berdampak terhadap kerusakan bangunan

Menurut Coburn dan Spence (1992), kerentanan didefinisikan "as the degree of loss to a given element at risk resulting from a given level of hazard". Dapat dikatakan bahwa kerentanan bangunan merupakan ketidakmampuan bangunan dalam menahan goncangan akibat tingkat bahaya gempa tertentu yang diperkirakan terjadi.

\subsection{Prinsip Bangunan Tahan Gempa}

Berikut adalah beberapa prinsip bangunan tahan gempa:

1. Bila terjadi gempa ringan, bangunan tidak boleh mengalami kerusakan baik pada komponen non-struktural maupun pada komponen strukturalnya.

2. Bila terjadi gempa sedang, bangunan boleh mengalami kerusakan pada komponen nonstrukturalnya (plafond runtuh, dinding retak) akan tetapi komponen struktural (kolom, balok, sloof) tidak boleh rusak.

3. Bila terjadi gempa besar, bangunan boleh mengalami kerusakan baik pada komponen non-struktural maupun komponen strukturalnya, akan tetapi jiwa penghuni bangunan tetap selamat, artinya sebelum bangunan runtuh masih cukup waktu bagi penghuni bangunan untuk keluar.

\subsection{Pengurangan Kerentanan berdasarkan Perpektif Perundangan}

Pengurangan kerentanan bangunan di Indonesia mengacu pada tataran normatif berlandaskan pada Pancasila dan Undang-Undang Dasar (UUD) 1945. Pada alinea ke IV pembukaan UUD 1945: "Kemudian daripada itu untuk membentuk suatu Pemerintahan Negara Indonesia yang melindungi segenap Bangsa Indonesia dan seluruh tumpah darah Indonesia"

Hal ini menyiratkan bahwa pemerintah Republik Indonesia (RI) dibentuk untuk melindungi (law and order) dan mensejahterakan rakyat (welfare). Perlindungan ini termasuk terjadinya bencana yang ditegaskan dalam UU No.24 Tahun 2007 Penanggulangan Bencana. Dinyatakan dalam undang-undang tersebut bahwa penanggulangan bencana merupakan urusan bersama pemerintah, masyarakat, dunia usaha, organisasi non-pemerintah, internasional, maupun pemangku kepentingan (stakeholders) lainnya. Oleh karenanya landasan nasional dalam penanggulangan bencana dan pengurangan risiko bencana akan memberikan advokasi dan dukungan kepada pemerintah dalam upaya melaksanakan pengurangan risiko bencana secara terencana, sistematis, dan menyeluruh. Pada tataran global, pelaksanaan dari undangundang tersebut juga merupakan upaya implementasi dari komitmen dunia yang tertuang dalam Kerangka Aksi Hyogo (Hyogo Framework for Action/HFA) 2005-2015 yang menjadikan bangsa Indonesia memiliki komitmen terhadap dunia internasional dalam pengurangan risiko bencana (Zulfiar dkk, 2017). Amanat Undang Undang No.24 Tahun 2007 dengan terbentuknya BNPB melalui Kepres No.8 Tahun 2008. Lembaga BNPB non departemen setingkat menteri mengusung visi "Ketangguhan bangsa dalam menghadapi bencana", dan misi "Melindungi bangsa dari ancaman bencana melalui pengurangan risiko, membangun sistem penanggulangan bencana yang handal, serta menyelenggarakan penanggulangan bencana secara terencana, terpadu, terkoordinir, dan menyeluruh".

\subsection{Kerentanan Bangunan berdasarkan FEMA-154}

FEMA 154 (2015) digunakan dengan pertimbangan menyediakan sebuah metodologi 
mengevaluasi keamanan seismik dari bangunan dengan akses minimum kebangunan, dan dimungkinkan pemeriksaan lebih rinci. FEMA mengembangkan metode untuk mengetahui kerentanan suatu bangunan dengan melakukan pengamatan untuk menilai besarnya kerentanan bangunan terhadap gempa. Hasil dari evaluasi kerentanan akan dijadikan pedoman dalam melakukan tindakan berikutnya sebagai langkah Risk Reduction terhadap ancaman gempa. Kerusakan bangunan berdasarkan form dari FEMA 154 terdiri dari beberapa penilaian dasar, seperti verifikasi dan memperbarui informasi indentifikasi bangunan, sketsa bangunan dan elevasi, menentukan tipe tanah tempat bangunan berdiri, menentukan dan dokumentasi pengguna bangunan, indentifikasi potensi bahaya bangunan, identifikasi Lateral-Load-Resisting System dan dokumentasi mengenai nilai dasar struktural yang berhubungan.

Apabila hasil evaluasi menunjukan bangunan belum memenuhi syarat, maka dapat dilakukan tindakan berikutnya yaitu diruntuhkan atau di perkuat dengan metode retrofitting, bracing, dan lain - lain (FEMA 172, FEMA 356).

\section{Metode Penilaian dan Objek Studi}

Bangunan rumah di nDalem Pujokusuman merupakan bangunan cagar budaya yang dilindungi oleh pemerintah. Bangunan tersebut terdiri dari sepuluh bangunan rumah dalam satu komplek terletak di jalan Brigjen Katamso Yogyakarta.

Selain penilaian dengan metode RVS, studi kualitatif juga digunakan dalam penelitian ini yang bertujuan untuk memperoleh penjelasan terhadap suatu fenomena (Jayady dkk., 2013; Jayady, 2017) pada objek penelitian ini.

Penilaian kerentanan berdasarkan prosedur RVS dilaksanakan dengan pengisian kuesioner khusus dengan pengamatan langsung suatu bangunan baik pada sisi eksterior maupun interior, kriteria dan hasilnya dapat dijelaskan sebagai berikut

\section{Lokasi Seismisitas}

Lokasi seismisitas adalah lokasi persebaran gempa. Pada Fema 154, lokasi seismisitas terbagi menjadi (lihat Tabel 1).
Tabel 1 Nilai respon spektrum

\begin{tabular}{|l|l|l|}
\hline $\begin{array}{l}\text { Lokasi } \\
\text { Seismis- } \\
\text { itas }\end{array}$ & $\begin{array}{l}\text { Akselerasi Respon } \\
\text { Spektrum/Ss } \\
\text { (periode } \\
\text { pendek/0.2t) }\end{array}$ & $\begin{array}{l}\text { Akselerasi Respon } \\
\text { Spektrum/ } \\
\text { (periode } \\
\text { panjang/0.1t) }\end{array}$ \\
\hline Rendah & $\mathrm{Ss}_{5} \leq 0.25 \mathrm{~g}$ & $\mathrm{~S}_{1} \leq 0.10 \mathrm{~g}$ \\
\hline Sedang & $0.25 \mathrm{~g} \leq \mathrm{S}_{\mathrm{S}} \leq 0.50 \mathrm{~g}$ & $0.1 \mathrm{~g} \leq \mathrm{S}_{1} \leq 0.20 \mathrm{~g}$ \\
\hline $\begin{array}{l}\text { Agak } \\
\text { tinggi }\end{array}$ & $0.50 \mathrm{~g} \leq \mathrm{Ss}_{\mathrm{s}} \leq 1.00 \mathrm{~g}$ & $0.20 \mathrm{~g} \leq \mathrm{S}_{1} \leq 0.40 \mathrm{~g}$ \\
\hline Tinggi & $1.00 \mathrm{~g} \leq \mathrm{S}_{\mathrm{S}} \leq 1.50 \mathrm{~g}$ & $0.40 \mathrm{~g} \leq \mathrm{S}_{1} \leq 0.60 \mathrm{~g}$ \\
\hline $\begin{array}{l}\text { Amat } \\
\text { tinggi }\end{array}$ & $\mathrm{Ss} \geq 1.50 \mathrm{~g}$ & $\mathrm{~S}_{1} \geq 0.60 \mathrm{~g}$ \\
\hline
\end{tabular}

(Sumber: FEMA P-154, 2015)

Data desain spectra (SS dan S1) didapatkan dari koordinat suatu bangunan yang ditinjau, yang kemudian diinput ke website Pusat Penelitian dan Pengembangan Permukiman (http://puskim. pu.go.id/Aplikasi/desain_spektra_indonesia_201 1/) (Kementrian PU, 2011). Posisi koordinat banguna dengan latitude -7.812431 dan longitude 110.369760, hasil input posisi koordinat akan menghasilkan nilai $\mathrm{S}_{\mathrm{S}}$ sebesar 1.290 dan $\mathrm{S}_{1}$ sebesar 0.467. NIlai $\mathrm{S}_{\mathrm{S}}$ dan $\mathrm{S}_{1}$ tersebut menunjukkan lokasi seismisitas katagori "Tinggi"

2. Hunian

Hunian ini memiliki karakteristik yang mudah dikenali dari RVS, umumnya mewakili spektrum luas penggunaan bangunan. Terdapat sembilan jenis/kelas hunian, yaitu: Gedung Pertemuan, Komersial, Layanan darurat, Industri, Kantor, Perumahan, Sekolah, Utilitas, Gudang. Obyek penelitian cagar budaya dapat dikategorikan "Perumahan"

\section{Jenis Tanah}

Identifikasi jenis tanah diperlukan untuk mengetahui tipe tanah yang ada di kawasan sekitar bangunan yang akan diinvestigasi. Menurut FEMA 154 (2015) Jenis tanah dibagi menjadi 6 jenis, yaitu: Hard Rock, Average Rock, Dense Soil, Stiff Soil, Soft Soil, Poor Soil.Berdasarkan pengamatan dilapangan jenis tanah dapat kategarikan "Soft soil"

4. Elemen yang mudah jatuh (falling hazard) Bahaya dari elemen bangunan yang nonstruktural seperti cerobong asap, parapet (dinding eksterior), lapisan atap, hiasan gantung, dan kanopi yang dapat mengakibatkan bahaya bagi keselamatan hidup penghuni. Meskipun sistem penahan gaya seismik dasar untuk bangunan mungkin memadai dan tidak memerlukan tinjauan lebih lanjut, jika ada bahaya semacam itu mungkin berbahaya bagi penghuni bangunan dan orang yang lewat. 


\section{Tipe bangunan}

Tipe bangunan dimaksudkan untuk menentukan tipe bangunan yang diamati. Menurut FEMA 154 (2015), terdapat 17 tipe bangunan. Berdasarkan pengamatan pada obyek penelitian terdapat 4 (empat) tipe: Rangka kayu, Perumahan/rumah hunian keluarga (W1); Bangunan rangka baja dengan dinding pengisi batu bata yang tidak diperkuat (S5); Bangunan dinding batu bata yang diperkuat dengan lantai fleksibel dan atap rongga (RM1); Bangunan dinding bata yang tidak diperkuat (URM).

\section{Jumlah Lantai}

Jumlah lantai diukur dari bagian bangunan paling bawah yang menyentuh tanah hingga atap. Berdasarkan hasil pengamatan di lapangan bangunan cagar budaya berlantai rendah yaitu 1 lantai

\section{Kedekatan (adjacency)}

Adjacency adalah kedekatan antara bangunan satu dengan lainnya. FEMA 154 (2015) membagi dua kategori yaitu; pounding (berjarak) atau falling hazard for taller adjacent building. Berdasarkan hasil pengamatan di lapangan, kedekatan antar bangunan memiliki jarak yang cukup

\section{Vertical irregularity}

Vertical Irregularity adalah penampakan vertikal bangunan yang tidak regular, seperti: (a) Sloping site yaitu Bangunan yang berada di atas bukit yang curam, terdapat masalah karena kekakuan horizontal di sepanjang sisi bawah mungkin berbeda dari sisi yang menanjak; (b) Soft story adalah kondisi dimana sebuah lantai bangunan memiliki kekuatan lebih kecil daripada lantai di atas atau di bawahnya, contohnya: Basemant; (c) Out-of-plane setback

terjadi ketika sistem penahan gaya seismik pada suatu lantai tidak selaras secara vertikal dengan sistem penahan gaya seismik di atas atau di bawahnya; (d) In-plane setback, kondisi ini terjadi ketika elemen-elemen dari sistem penahan gaya seismik di tingkat atas diimbangi dengan elemen-elemen dari sistem penahan gaya seismik pada tingkat yang lebih rendah. Hal ini biasanya dapat diamati pada struktur rangka dan dinding geser. Kerusakan dapat terkonsentrasi pada elemen horisontal yang menghubungkan elemen lateral dan elemen vertikal yang terjadi di bawah elemen lateral pada tingkat atas; (e) Short column, bila beberapa kolom (atau kolom dinding) lebih pendek dari pada kolom pada umumnya, kolom yang lebih pendek dan lebih kaku ini menarik lebih banyak muatan lateral. Akibatnya, dapat mengalami kerusakan yang signifikan; (f) Split levels, kondisi terjadi dimana lantai atau atap di salah satu bagian bangunan

\section{Plan Irregularity}

Plan Irregularity adalah bentuk denah yang tidak simetris. Meskipun ketidakteraturan rencana dapat terjadi pada semua tipe bangunan, perhatian utamanya terletak pada bingkai kayu, tilt-up, pre-cast, batu bata yang diperkuat, dan konstruksi pasangan bata yang tidak diperkuat. Beberapa bentuk plan irregularity sebagai berikut: (a) Torsio, kondisi berlaku bila bangunan memiliki hambatan beban lateral yang pasti atau baik dalam satu arah namun tidak pada yang lain. Juga pada kondisi terdapat eksentrisitas dengan kekakuan besar pada sistem penahan gaya seismik yang dapat menyebabkan putaran (torsi) di sekitar sumbu vertikal. Penyimpangan dalam perencanaan yang mengakibatkan torsi sering terjadi pada bangunan sudut dimana dua sisi yang berdekatan memiliki bukaan jendela yang signifikan sedangkan sisi lainnya kokoh; (b) Non-parallel system adalah bentuk bangunan yang berbentuk: runcing, berbentuk segitiga, terdapat sudut yang tidak memenuhi 90 derajat, dan rentan terhadap torsi yang berpotensi rusak dan runtuh; (c) Reentrant corners, Bangunan dengan sudut sayap panjang yang berbentuk E, L, $\mathrm{T}, \mathrm{U}$, atau + (Gambar 1). Konsentrasi tegangan dapat berkembang pada sudut reentrant dan menyebabkan kerusakan atau keruntuhan.

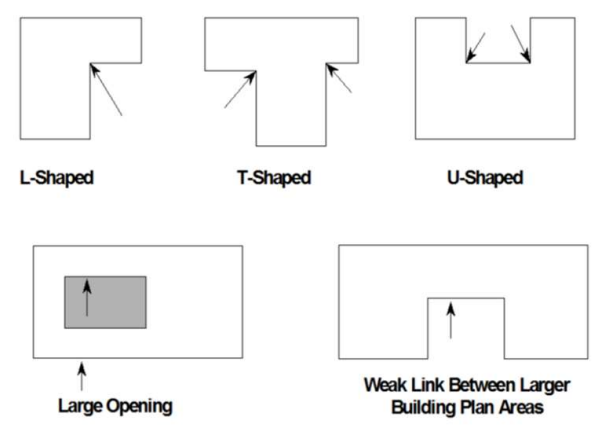

Gambar 1. Bentuk bangunan reentrant corners plan irregularity ( Sumber : FEMA P-154, 2015

(d) Diaphragm openings, Bukaan besar pada lantai atau atap melemahkan diafragma dan mengurangi kemampuannya untuk mentransfer kekuatan seismik. Bukaan ini terjadi untuk fitur arsitektur, seperti pada roof skylight; (e) Beams do not align with coloumns, Balok tidak sejajar 
dengan kolom. Kondisi ini terjadi bila balok eksterior tidak sejajar dengan kolom dalam rencana; (f) Code saat pembangunan bisa diketahui dengan melihat tahun bangunan itu didirikan. Untuk code yang berlaku di Indonesia, disebut Pre-code apabila dibangun sebelum tahun 1971 (PBI 1971) dan disebut PostBenchmark bila dibangun setelah tahun 1992 (SNI 1992);

\section{Diskusi}

Selanjutnya berdasarkan sembilan kriteria tersebut di atas, dapat ditentukan skor bangunan tersebut, dengan cara melingkari skor pada tipe bangunan (building type) yang cocok dengan bangunan yang dievaluasi. Kemudian seluruh skor tersebut dijumlahkan dan diperoleh skor akhir (S). Apabila S kurang atau sama dengn 2 maka bangunan dinyatakan berisiko terhadap ancaman gempa, dan perlu dilakukan evaluasi lebih detail.

Score $S_{L I}$ didapatkan basic score bangunan yang di kurangi dengan tingkat kesalahan atau potensi bangunan rentan terhadap gempa yang diperoleh dari rapid visual screening (RVS). $\mathrm{S}_{\mathrm{L} 1}$ kemudian dapat dianalisis dengan mendapatkan skor akhir dengan Persamaan 1.

Skor akhir $(\mathrm{S})=\frac{1}{10^{S L 1}}$

Bila $\mathrm{S}_{\mathrm{L} 1}=2$, maka kemungkinan 1 bangunan rentan terhadap gempa atau berpotensi roboh dari 100 banguanan atau $1 \%$ bangunan yang ditinjau memiliki resiko rentan terhadap gempa atau berpotensi roboh dari keseluruhan bangunan.

Hasil penilaian dari pengamatan dan interview dapat di lihat pada Tabel 2.

Tabel 2 Penilaian bangunan berdasarkan RVS

\begin{tabular}{|c|c|c|c|c|c|c|c|c|c|c|}
\hline 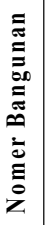 & 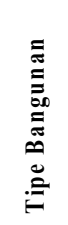 & 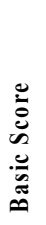 & 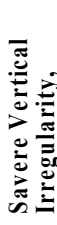 & 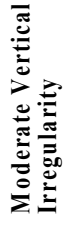 & 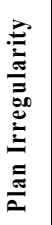 & $\begin{array}{l}\stackrel{0}{0} \\
\dot{d} \\
\dot{d} \\
\text { D. }\end{array}$ & 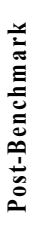 & 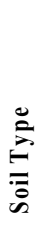 & 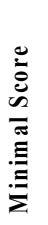 & 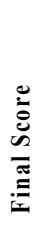 \\
\hline 1 & URM & 1,0 & - & $-0,4$ & $-0,4$ & - & - & D & 0.2 & 0.2 \\
\hline 2 & URM & 1,0 & - & $-0,4$ & -0.4 & - & - & $\mathrm{D}$ & 0.2 & 0.2 \\
\hline 3 & RM1 & 1,7 & - & -0.5 & -0.7 & - & - & $\mathrm{D}$ & 0.3 & 0.5 \\
\hline 4 & S5 & 1,7 & - & - & -0.6 & -0.2 & - & $\mathrm{D}$ & 0.5 & 0.9 \\
\hline 5 & URM & 1,0 & - & $-0,4$ & $-0,4$ & - & - & $\mathrm{D}$ & 0.2 & 0.2 \\
\hline \multirow{2}{*}{6} & RM1 & 1,7 & - & -0.5 & -0.7 & - & 2.1 & $\mathrm{D}$ & 0.3 & 2.6 \\
\hline & W1 & 3.6 & - & -0.7 & -1.1 & - & 1.6 & $\mathrm{D}$ & 1.1 & 3.4 \\
\hline 7 & RM1 & 1.7 & - & -0.5 & -0.7 & - & 2.1 & D & 0.3 & 3.1 \\
\hline 8 & W1 & 3.6 & - & - & -1.1 & -1.1 & - & $\mathrm{D}$ & 1.1 & 1.4 \\
\hline 9 & W1 & 3.6 & - & - & - & -1.1 & - & $\mathrm{D}$ & 1.1 & 2.5 \\
\hline 10 & URM & 1,0 & - & $-0,4$ & $-0,4$ & . & - & $\mathrm{D}$ & 0.2 & 0.2 \\
\hline
\end{tabular}

(Sumber: Survey Lapangan, 2017)

Dari Tabel 2 dapat diketahui bahwa final score tertinggi terdapat pada bangunan no. 6 dengan final score sebesar 3.4 dan 2.6 pada bangunan kategori W1 dan RM1. Walaupun bangunan tersebut memiliki faktor plan irregularity dan moderate vertical irregularity, diketahui bahwa kedua faktor tersebut mempengaruhi pengurangan final score terhadap suatu bangunan, akan tetapi pada bangunan no.6 yaitu bangunan yang terencana oleh ahli struktur dengan mengacu aturan SNI 1992 (faktor postbenchmark). Sedangkan final score terendah yaitu pada kategori bangunan URM degan final score minimum, yaitu 0.2 .

Adapun langkah selanjutnya yaitu menganalisis Final score, untuk mengetahui prosentase potemsi kerentanan dari bangunan yang ditinjau (lihat Tabel 3).

Tabel 3 Analisis Final score

\begin{tabular}{|l|l|l|l|}
\hline $\begin{array}{l}\text { No. } \\
\text { Bangunan }\end{array}$ & $\begin{array}{l}\text { Final } \\
\text { Score (S) }\end{array}$ & $\frac{1}{\mathbf{1 0}^{\boldsymbol{s}}}$ & $\begin{array}{l}\text { Potensi } \\
\text { Kerentanan (\%) }\end{array}$ \\
\hline 1 & 0.2 & 0.6309 & 63.09 \\
\hline 2 & 0.2 & 0.6309 & 63.09 \\
\hline 3 & 0.5 & 0.3162 & 31.62 \\
\hline 4 & 0.9 & 0.1259 & 12.59 \\
\hline 5 & 0.2 & 0.6309 & 63.09 \\
\hline 6 & 2.6 & 0.0025 & 0.25 \\
\hline 3.4 & 0.00039 & 0.039 \\
\hline 7 & 3.1 & 0.00079 & 0.079 \\
\hline 8 & 1.4 & 0.039 & 3.98 \\
\hline 9 & 2.5 & 0.0031 & 0.31 \\
\hline 10 & 0.2 & 0.6309 & 63.09 \\
\hline Rata-rata & .3 & 0.2738 & 27.38 \\
(Sumber: Survey Lapangan, 2017$)$ &
\end{tabular}


Dari Tabel 3 di atas maka dapat dijelaskan sebagai berikut :

1. Rumah no. 1 merupakan bangunan URM memiliki nilai $\mathrm{S}$ sebesar 0.2 dengan final score 0.63 , dapat diartikan $63 \%$ bangunan tersebut rentan terhadap gempa atau berpotensi roboh.

2. Rumah no. 2 merupakan bangunan URM memiliki nilai $\mathrm{S}$ sebesar 0.2 dengan final score 0.63 , dapat diartikan $63 \%$ bangunan tersebut rentan terhadap gempa atau berpotensi roboh.

3. Rumah no. 3 merupakan bangunan RM1 memiliki nilai $\mathrm{S}$ sebesar 0.5 dengan final score 0.32 , dapat diartikan $32 \%$ bangunan tersebut rentan terhadap gempa atau berpotensi roboh.

4. Rumah no. 4 merupakan bangunan S5 memiliki nilai $\mathrm{S}$ sebesar 0.9 dengan final score 0.13 , dapat diartikan $13 \%$ bangunan tersebut rentan terhadap gempa atau berpotensi roboh.

5. Rumah no. 5 merupakan bangunan URM memiliki nilai $\mathrm{S}$ sebesar 0.2 dengan final score 0.63 , dapat diartikan $63 \%$ bangunan tersebut rentan terhadap gempa atau berpotensi roboh.

6. Rumah no. 6 merupakan bangunan W1 memiliki nilai $\mathrm{S}$ sebesar 3.4 dengan final score 0.0003, dapat diartikan $0.03 \%$ bangunan tersebut rentan terhadap gempa atau berpotensi roboh. Sedangkan Bangunan RM1 memiliki nilai S sebesar 2.6 dengan final score 0.025 dapat diartikan $0.25 \%$ berpotensi roboh atau rentan terhadap gempa.

7. Rumah no. 7 merupakan bangunan RM1 memiliki nilai $\mathrm{S}$ sebesar 0.5 dengan final score 0.32 , dapat diartikan $32 \%$ bangunan tersebut rentan terhadap gempa atau berpotensi roboh.

8. Rumah no. 8 merupakan bangunan W1 memiliki nilai $\mathrm{S}$ sebesar 1.4 dengan final score 0.03 , dapat diartikan $4 \%$ bangunan tersebut rentan terhadap gempa atau berpotensi roboh.

9. Rumah no. 9 merupakan bangunan W1 memiliki nilai $\mathrm{S}$ sebesar 2.5 dengan final score 0.003 , dapat diartikan $0.3 \%$ bangunan tersebut rentan terhadap gempa atau berpotensi roboh.

10.Rumah no. 10 merupakan bangunan URM memiliki nilai $\mathrm{S}$ sebesar 0.2 dengan final score 0.63 , dapat diartikan $63 \%$ bangunan tersebut rentan terhadap gempa atau berpotensi roboh.

Rata-Rata bangunan rumah hunian di nDalem Pujokusuman memiliki nilai $\mathrm{S}$ sebesar 1.3 dengan final score 0.27 dapat diartikan rentan terhadap gempa dengan potensi roboh sebesar $27 \%$ dari seluruh bangunan apabila gempa besar terjadi.

Dari Tabel 3 dilakukan analisis kerentanan bangunan terhadap kategori bangunan dan hasilnya dapat dilihat pada Tabel 4 berikut ini.

Tabel 4 Hasil analisis kerentanan bangunan berdasarkan kategori bangunan

\begin{tabular}{|l|l|l|l|l|}
\hline No & $\begin{array}{l}\text { Kategori } \\
\text { Banguan }\end{array}$ & $\begin{array}{l}\text { Score } \\
\text { Rata }- \\
\text { Rata }\end{array}$ & $\frac{1}{10^{s}}$ & $\begin{array}{l}\text { Potensi } \\
\text { Kerentanan } \\
\mathbf{( \% )}\end{array}$ \\
\hline 1 & URM & 0.2 & 0.6309 & 63.09 \\
\hline 2 & S5 & 0.9 & 0.12589 & 12.59 \\
\hline 3 & RM1 & 2.0 & 0.01 & 1 \\
\hline 4 & W1 & 2.4 & 0.0039 & 0.39 \\
\hline
\end{tabular}

Dari Tabel 4 di atas maka dapat dijelaskan sebagai berikut :

1. Bangunan URM memiliki $\mathrm{S}$ sebesar 0.2 dengan final score 0.63 , dapat diartikan $63 \%$ bangunan tersebut rentan terhadap gempa atau berpotensi roboh. Hal tersebut dikarenakan karena bangunan URM merpakan cagar budaya yang memiliki nilai histori yang dibangun tanpa mengacu pada aturan atau code yang berlaku.

2. Bangunan S5 memiliki S sebesar 0.9 dengan final score 0.125 , dapat diartikan $12.5 \%$ bangunan tersebut rentan terhadap gempa atau berpotensi roboh. Hal tersebut dikarenakan karena bangunan S5 memiliki pondasi yang masih merpakan cagar budaya yang memiliki nilai histori yang dibangun tanpa mengacu pada aturan atau code yang berlaku kemudian.

3. Bangunan RM1 memiliki $\mathrm{S}$ sebesar 2.0 dengan final score 0.01, dapat diartikan 1\% bangunan tersebut rentan terhadap gempa atau berpotensi roboh. Kesalahan pada denah rumah yang tidak simetris dan moderate vertical irregularity tanpa mengacu kepada aturan atau kode yang berlaku.

4. Bangunan $\mathrm{W} 1$ memiliki S sebesar 2.4 dengan final score 0.004, dapat diartikan $0.4 \%$ bangunan tersebut rentan terhadap gempa atau berpotensi roboh. Hal tersebut dikarenakan bangunan W1 merupakan bangunan konstruksi kayu dengan denah rumah yang sederhana dan simetris membuat 
bangunan ini tahan terhadap resiko gempa bumi.

\section{Kesimpulan}

Berdasarkan dari hasil analisis menggunakan Rapid Visual Screening of Buildings for Potential Seismic Hazard bentuk bangunan rumah di nDalem Pujokusuman dapat kesimpulan sebagai berikut:

1. Bangunan tersebut merupakan bangunan non-engineered yang berada pada daerah rawan gempa tinggi, sehingga bangunan tersebut rentan terhadap gempa dan berpotensi roboh jika gempa besar terjadi.

2. Factor bentuk yang menyebabkan bangunan rentan terhadap gempa adalah Plan irregularity, Vertical irregularity, belum adanya acuan pembangunan atau code saat pembangunan yang dirujuk, dan perawatan bangunan pada bangunan cagar budaya (non-engineered).

3. Memiliki nilai rata-rata $\mathrm{S}$ sebesar 1.5 dengan final score 0.03 dapat diartikan kerentanan bangunan terhadap gempa sebesar 3\% dari seluruh bangunan akan roboh.

\section{Daftar Pustaka :}

Creswell, J.W. (2010). Research Design: Qualitative, Quantitaive, and Mixed Methods Approaches, SAGE Publications Inc., 2455 Teller Road, Thousand Oaks, California 91320.

Coburn, A. dan Spence, R. (1992): Earthquake Protection, John Wiley \& sons, England

FEMA 154. 2015. Rapid Visual Screening of Buildings for Potential Seismic Hazard : A Handbook, Third Edition. Federal Emergency Management Agency, USA.

Jayady, A. (2017). "Joint Operation dalam Studi Kualitatif”, Jurnal Karkasa, Vol. 3.1, Politeknik Katolik Saint Paul Sorong, Indonesia.

Jayady, A., Pribadi, K.S., Abduh, M., \& Bahagia, S.N. (2017). "Model Penilaian Keberhasilan Transfer of Knowledge pada Joint Operation antara Perusahaan Jasa Konstruksi Asing dan Perusahaan Jasa Konstruksi Lokal", Disertasi Doktor, Fakultas Teknik Sipil dan Lingkungan, Institut Teknologi Bandung (ITB), Bandung, Indonesia.
Jayady, A., Pribadi, K.S., Abduh, M., \& Bahagia, S.N. (2013). "Perkembangan Joint Operation di Indonesia", Prosiding : Seminar Nasional Teknik Sipil IX, Institut Teknologi Sepuluh November - Surabaya, 9 February 2013

Jayady, A., Pribadi, K.S., Abduh, M., \& Bahagia, S.N. (2013). "A Study of Joint Operation Scheme in Indonesia", Prosiding : The ${ }^{T H}$ Civil Engineering Confrence in The Asian Region, 20-22 Agustus 2013.

Kepala BNPB. (2012). Peraturan Kepala Badan Nasional Penanggulangan Bencana nomor 2 tahun 2012 tentang Pedoman Umum Pengkajian Risiko Bencana.

Kurniawandy, dkk. 2015. Evaluasi Kerentanan Bangunan Gedung Terhadap Gempa Bumi dengan Rapid Visual Screening (RVS) Berdasarkan FEMA $154 . \quad$ Prosiding: The Annual Civil Engineering Seminar Pekanbaru, $338-345$.

Kramer, S.L. (2014): Geothecnical Eartquake Engineering, Peason, United States of America.

Sekaran, U. (2003). Research Methods for Business - A Skill building Approach, Souther Illinois University at Carbondale, John Wiley \& Sons Inc., USA.

Presiden Republik Indonesia. (2007). UndangUndang Republik Indonesia nomor 24 tahun 2007 tentang Penanggulangan Bencana.

Presiden Republik Indonesia. (2008). Peraturan Pemerintah Republik Indonesia nomor 21 tahun 2008 tentang Penyelenggaraan Penanggulangan Bencana.

Kementerian Pekerjaan Umum (2011). Desain Spektra Indonesia, 2011. Pusat Penelitian dan Pengembangan Pemukiman PPMB ITB,Bandung. (http://puskim.pu.go.id/ Aplikasi/desain_spektra_indonesia_2011/)

Zulfiar, M. Heri. 2014. Identifikasi Faktor Dominan Penyebab Kerentanan Bangunan di Daerah Rawan Gempa, Provinsi Sumatera Barat. Jurnal Ilmiah Semesta Teknika, 17(2), $116-125$.

Zulfiar, M.H., Tamin, R.Z., Pribadi, K.S., \& Imran, I. (2017). "Kajian Kebijakan sektor Konstruksi untuk Mereduksi Kerentanan Bangunan terhadap Gempa", Disertasi Doktor, Fakultas Teknik Sipil dan Lingkungan, Institut Teknologi Bandung (ITB), Bandung, Indonesia. 